\title{
STUDY OF KINETIN TRAETMENT ON GROWTH AND ACTIVITY OF SOME ANTIOXIDANT ENZYMES OF SPINACH UNDER SALT STRESS
}

\author{
Duraid K.A. AL-Taey ${ }^{1}$, Saadoon A.H. Saadoon ${ }^{2}$, Saad S.M. ALAzawi ${ }^{1}$ \\ ${ }^{1}$ Department of Horticulture, Faculty of Agriculture, University of AL-Qasim green, Iraq \\ ${ }^{2}$ Biology department, Faculty of Education of woman, University of Kufa, Iraq
}

\section{Current Trends in}

\section{Natural Sciences}

\begin{abstract}
Soil salinity reduces water availability of plant roots via negative (low) osmosis potential, as well as decrease of germination dynamics of plant seeds by ionic toxicity of $\mathrm{Na}$ and $\mathrm{Cl}$, Significant differences in fruit-set, yield, photosynthetic rates, stomatal conductance, total chlorophyll content, proline, In general, salinity affects almost every aspect of the physiology and biochemistry of plants. This experiment was conducted on a private farm in Babylon Governorate at the period from 1/10/ 2013 to 15/5/ 2014, to study the effect of Kinetin treatment with three concentrations $(0,20 \& 40 \mathrm{mg}$ /liter $)$ and the quality of irrigation water in three levels $(1.3,5 \& 10) \mathrm{dS} . \mathrm{m}^{-1}$ the water salinity increased the POX and CAT activity, sodium and proline contents in leaves, resulting in decreased growth and leaf contents of NPK, The Kinetin applications alleviated negative effects of saline water by increasing dry weights of roots and NPK contents in leaves with an increasing of POX and CAT activity, and reduction of sodium contents in leaves.
\end{abstract}

Keywords: CAT, Kinetin, POX, Oxidative stress, Salinity

\section{INTRODUCTION}

Spinach is an important leafy green vegetable that contains large quantities of bioactive compounds and nutrients that are not common to most other vegetables, such as r-coumaric acid derivatives that exhibit strong antioxidant activity and glucuronic acid derivatives of flavonoids (AL-Taey and Saadoon, 2012; $\mathrm{Xu}$ and $\mathrm{Mou}, 2016$ ). It was identified as a moderately salt-sensitive vegetable (Shannon and Grieve, 1999). Salt stress reduced spinach germination, root elongation, seedling growth, chlorophyll content and photosynthesis, and increased membrane permeability (Kaya et al., 2002).

High-salinity conditions in agricultural soil and irrigation water is one of the most serious challenges faced by agricultural crops in the world. It is estimated that salt-affected soils impact nearly $10 \%$ of the land surface and $50 \%$ of irrigated land in the world (AL-Taey, 2009; Ruan et al., 2010), Secondary salinization from irrigation water is a growing worldwide problem as more than $6 \%$ of agricultural land has become saline, Soil salinity reduces water availability of plant roots via negative (low) osmosis potential, as well as decrease of germination dynamics of plant seeds by ionic toxicity of $\mathrm{Na}$ and $\mathrm{Cl}$, Significant differences in fruit-set, yield, photo synthetic rates, stomatal conductance, total chlorophyll content, proline, In general, salinity affects almost every aspect of the physiology and biochemistry of plants (Abass et al., 2015 ; AlTaey, 2017), the mechanism of 
plant tolerance in the non-salty plants to be happened by more then way, by avoid absorbed salty ions such as $\mathrm{Na}$ or it's have other mechanism involved to discarding the $\mathrm{Na}$ and $\mathrm{Cl}$ from cells and keep on high levels of $\mathrm{K}$ in the cells, the other mechanism involved with the cell ability of osmoregulation by raised the osmotic pressure of cell to obverse the outer osmotic pressure and absorb the water from the soil solution (Al-Khafajy et al., 2020).

Phytohormones are the most important endogenous substances for moderating physiological and molecular responses, a critical requirement for plant survival, Phytohormones act at their site of synthesis or elsewhere in plants following their transport (Shabir et al., 2016), Plant growth regulators are being widely used to counteract the deleterious effects of adverse environmental stresses on plants. The treatments with an optimal concentration of Phytohormones has been shown to be beneficial to the growth and yield of some crop species growth under saline conditions by increasing nutrient reserves through increased physiological activities and root proliferation, Concerted attempts have been made to mitigate the harmful effects of salinity by application of plant growth regulators (Al-Taey et al., 2009; Al-Taey and Majid, 2018).

Kinetin is one of the Cytokinins known to significantly improve the growth of crop plants grown under salinity, there are many researchers conducted about Kinetin ability to improve the plant growth under salt stress by deleterious of sodium toxicity and raised potassium rate inside the plant besides Kinetin role to enzyme activation (Hamza and AL-Taey, 2020). The study aims to test the effect of Kinetin application to reduce the damage of salinity by different water qualities with three levels on some growth parameters and Yield.

\section{MATERIALS AND METHODS}

The experiment was conducted in a field located at Al-Muradia \Babylon Governorate during the winter growing season of 2013-2014, the Spinach seed was a local Iraqi cultivar, many soil samples were taken from the field randomly to analyze some physical and chemical characters as shown at a table (1), the chemical drainage water characters as show table (2). After the seed soaking of kinetin, it's sowed inside plots $(2 * 3 \mathrm{~m})$ as lines the distance between them $30 \mathrm{~cm}$ and between the plants $10 \mathrm{~cm}$ the total was 200 plants to each plot.

The experiment included studying the effect of water quality with three qualities, seeds soaking of Kinetin with three levels, and interaction between them to improve the growth, yield and some chemical characters by testing the role of Kinetin to reduce the negative effects by using the saline drainage water included three levels $\left(1.3,5 \& 10 \mathrm{dS} . \mathrm{m}^{-1}\right)$. The drainage water was mixing with river water to get $5 \& 10 \mathrm{dS} . \mathrm{m}^{-1}$ by 2 basins in the ground; the capacity to each one was 10000 liter, The treatments; the Kinetin application $(0,20,40 \mathrm{mg} / \mathrm{L})$, The experiment conducted as a factorial experiment by split-plot design with 9 treatments, each one had three replicate comparison was done using Least significant difference (L.S.D) to compare values with a probability of 0.05 level.

\section{The study parameters}

- The dry weight of roots.

- Vegetative yield (ton/ hectare), the total yield was calculated by made two cuts, the first cut at 50 days after sowing and the second cut at 75 days after sowing.

- The leaves contents of Nitrogen: the determination of $\mathrm{N}$ according to (Pregl, 1945).

- The leaves contents of Sodium \& potassium was determined by a Flame photometer

- The leave contents of Phosphorus was determined using the Ammonium molybdate by spectrophotometer at wavelength $882 \mathrm{~nm}$ (Page et al., 1982). 
Current Trends in Natural Sciences

Vol. 10, Issue 19, pp. 457-465, 2021

https://doi.org/10.47068/ctns.2021.v10i19.061

Current Trends in Natural Sciences (on-line)

- The leave content of chloride was determined by titration with AgNO3 (Richards, 1954).

- The Peroxidase activity was determined according to Adam et al. (1995) after 75 days of culture, the assay contained $1.5 \mathrm{ml}$ of $100 \mathrm{mM}$ sodium acetate buffer ( $\mathrm{pH} 5.5$ ), $1 \mathrm{ml}$ of $1 \mathrm{mM}$ guaiacol, $10 \mu \mathrm{l}$ of tissues extract and $190 \mu \mathrm{l}$ water. The reaction was started by the addition of $300 \mu \mathrm{l}$ of $1.3 \mathrm{mM} \mathrm{H} 2 \mathrm{O} 2$. The increase in absorbance at $470 \mathrm{~nm}$ was recorded for $3 \mathrm{~min}$.

- The Catalase activity determined after 75days, estimated according to the procedure of Aebi (1983) on the wave length $240 \mathrm{~nm}$ and the estimation of enzyme according to next formulas. $=\mathrm{A} 1 / \mathrm{A} 2 * 2.3 / \Delta \mathrm{t}^{*} \mathrm{Vt} / \mathrm{VS} \mu \mathrm{mol} \mathrm{Ca} ;$ Cat $\mu$ mole $* 1 / \mathrm{C}=\mu$ mole. $\mathrm{g}^{-1}$ Fresh weight

A1: Absorbance at zero time, A 2: Absorbance after 30 second

$\Delta \mathrm{t}$ : time of Absorbance 30 second, VT: the volume of total solution

VS: the volume of sample $=20 \mathrm{ml}$

\begin{tabular}{|c|c|c|}
\hline Soil separates & Texture & $\%$ \\
\hline Sand & & 0.42 \\
\hline Silt & Loam & 0.33 \\
\hline Clay & & 0.25 \\
\hline $\begin{array}{l}\text { Chemical } \\
\text { characters }\end{array}$ & unit & \\
\hline $\mathrm{Ec}$ & $\mathrm{dS}^{-1}$ & 2.8 \\
\hline $\mathrm{pH}$ & - & 7.22 \\
\hline \multicolumn{3}{|l|}{ Soluble ions } \\
\hline $\mathrm{Ca}^{++}$ & meq /L & 12.96 \\
\hline $\mathrm{Mg}^{++}$ & $\mathrm{meq} / \mathrm{L}$ & 8.73 \\
\hline $\mathrm{Na}^{+}$ & $\mathrm{meq} / \mathrm{L}$ & 7.44 \\
\hline $\mathrm{K}^{+}$ & meq /L & 0.52 \\
\hline $\mathrm{Co} 3^{=}$ & meq $/ \mathrm{L}$ & - \\
\hline $\mathrm{HCO}^{-}$ & meq /L & 0.71 \\
\hline $\mathrm{Cl}^{-}$ & $\mathrm{meq} / \mathrm{L}$ & 11.87 \\
\hline $\mathrm{SO} 4=$ & $\mathrm{meq} / \mathrm{L}$ & 13.56 \\
\hline
\end{tabular}

Table 2. The chemical analysis of drainage water

\begin{tabular}{|c|c|c|c|c|c|c|c|c|c|}
\hline \multicolumn{10}{|c|}{ Drainage water analysis } \\
\hline $\begin{array}{l}\mathrm{Ec} \\
\mathrm{dS}^{-}\end{array}$ & $\mathrm{pH}$ & $\begin{array}{c}\mathrm{Ca}^{+2} \\
\text { mmole/L }\end{array}$ & $\begin{array}{c}\mathrm{Mg}^{+2} \\
\text { mmole/L }\end{array}$ & $\begin{array}{c}\mathrm{Na}^{+} \\
\text {mmole/L }\end{array}$ & $\begin{array}{c}\mathrm{K}^{+} \\
\mathrm{mmole} / \mathrm{L}\end{array}$ & $\begin{array}{c}\mathrm{Co}^{-2} \\
\text { mmole/L }\end{array}$ & $\begin{array}{l}\mathrm{HCO}^{-} \\
\text {mmole/L }\end{array}$ & $\begin{array}{c}\mathrm{Cl}^{-} \\
\text {mmole/L }\end{array}$ & $\begin{array}{c}\mathrm{SO}^{-2} \\
\text { mmole/L }\end{array}$ \\
\hline 5 & 6.76 & 27.74 & 17.11 & 38.75 & 0.48 & - & 0.81 & 27.21 & 26.41 \\
\hline 10 & 6.82 & 47.15 & 38.18 & 44.09 & 0.54 & & 0.65 & 59.91 & 62.61 \\
\hline
\end{tabular}




\section{RESULTS AND DISCUSSIONS}

Roots dry weight: Table (3) showed that treatment which irrigated with $1.2 \mathrm{dS} . \mathrm{m}^{-1}$ achieved the highest values of dry weight compared to other water qualities significantly.

The Kinetin treatment improved the dry weights of root for both levels $(20 \& 40)$ mg.L - $^{-1}$ compared to treatments untreated with Kinetin, the interaction between water quality, Kinetin treatment achieved a significant difference, the treatment which irrigated with $1.2 \mathrm{dS} . \mathrm{m}^{-1}$ and treated with 20 $\& 40 \mathrm{mg} . \mathrm{L}^{-1}$ achieved the highest values.

\begin{tabular}{|c|c|c|c|c|}
\hline \multirow{2}{*}{$\begin{array}{l}\text { Water } \\
\text { quality }\end{array}$} & \multicolumn{3}{|c|}{ Kinetin mg. $\mathrm{L}^{-1}$} & \multirow{2}{*}{$\begin{array}{c}\text { Effect of } \\
\text { Water quality }\end{array}$} \\
\hline & 0 & 20 & 40 & \\
\hline $1.2 \mathrm{dS} . \mathrm{m}^{-1}$ & 2.847 & 3.187 & 3.193 & 3.076 \\
\hline $5 \mathrm{dS} . \mathrm{m}^{-1}$ & 2.050 & 2.367 & 2.370 & 2.262 \\
\hline \multirow[t]{3}{*}{10 dS.m ${ }^{-1}$} & 1.257 & 1.407 & 1.390 & 1.351 \\
\hline & \multicolumn{3}{|c|}{ L.S.D0.05 } & L.S.D0.05 \\
\hline & \multicolumn{3}{|c|}{0.248} & 0.201 \\
\hline $\begin{array}{l}\text { Effect of } \\
\text { Kinetin }\end{array}$ & 2.051 & 2.320 & 2.318 & \\
\hline L.S.D0.05 & & 0.140 & & \\
\hline
\end{tabular}

Yield: The results presented in table (4) showed significant differences between the values, the treatment which irrigated with $1.2 \mathrm{dS} . \mathrm{m}-1$ records the heights values of yields, while the treatments which irrigated $10 \mathrm{dS} \cdot \mathrm{m}^{-1}$ records lower values of yields, The yield average increased with Kinetin treatment with $40 \& 20 \mathrm{mg} . \mathrm{L}^{-1}$, the $40 \mathrm{mg} . \mathrm{L}^{-1}$ achieved the highest values without significant difference from $20 \mathrm{mg} . \mathrm{L}^{-1}$, table (4) presented significant differences between the interaction between the water quality \& Kinetin, the best treatments were irrigated with $1.2 \mathrm{dS} . \mathrm{m}^{-1}$ and treated with Kinetin whether 40 or $20 \mathrm{mg} . \mathrm{L}^{-1}$.

\begin{tabular}{|c|c|c|c|c|}
\hline \multirow{2}{*}{$\begin{array}{l}\text { Water } \\
\text { quality }\end{array}$} & \multicolumn{3}{|c|}{ Kinetin mg.L $\mathrm{L}^{-1}$} & \multirow{2}{*}{$\begin{array}{c}\text { Effect of } \\
\text { Water quality }\end{array}$} \\
\hline & 0 & 20 & 40 & \\
\hline $1.2 \mathrm{dS} . \mathrm{m}^{-1}$ & 11.743 & 12.230 & 12.570 & 3.076 \\
\hline $5 \mathrm{dS} . \mathrm{m}^{-1}$ & 8.523 & 9.039 & 9.280 & 2.262 \\
\hline \multirow[t]{2}{*}{$10 \mathrm{dS} \cdot \mathrm{m}^{-1}$} & 5.023 & 6.012 & 6.663 & 1.351 \\
\hline & \multicolumn{3}{|c|}{ L.S.D 0.05} & $\begin{array}{c}\text { L.S.D } 0.05 \\
0.317\end{array}$ \\
\hline $\begin{array}{c}\text { Effect of } \\
\text { Kinetin }\end{array}$ & 8.430 & 9.347 & 9.504 & \\
\hline L.S.D 0.05 & & 0.239 & & \\
\hline
\end{tabular}


Leaves contents of $\mathbf{N \%}$ : Table (5) showed a significant reduction of leaves contents of $\mathrm{N}$ with raised salt stress, the lower values at the treatments which irrigated with $10 \mathrm{dS} . \mathrm{m}^{-1}$, while the treatments which irrigated with $1.2 \mathrm{dS} . \mathrm{m}^{-1}$ achieved the biggest values compared to other of qualities, irrigation water.

Kinetin improved the leaves contents of $\mathrm{N}$, the concentration of kinetin $40 \mathrm{mg} . \mathrm{L}^{-1}$ achieved the highest values with the significantly, while the interaction between water quality, kinetin treatment record the significant difference between the values, the treatment which irrigated with $1.2 \mathrm{dS} . \mathrm{m}^{-1}$ $\&$ treated with $40 \mathrm{mg} . \mathrm{L}^{-1}$ record the highest value.

Table 5. Effect of water quality, kinetin treatment on Leaves contents of N\%

\begin{tabular}{ccccc} 
Water & \multicolumn{3}{c}{ Kinetin mg.L-1 } & $\begin{array}{c}\text { Effect of } \\
\text { quality }\end{array}$ \\
Water quality
\end{tabular}

Leaves contents of $\mathbf{P \%}$ : The results of table (5) showed a significant reduction in leaves contents of $\mathrm{P}$ with raised water salinity, the lower values at the treatments, which irrigated with $10 \mathrm{dS} . \mathrm{m}^{-1}$, while the treatments which irrigated with $1.2 \mathrm{dS} . \mathrm{m}-1$ record the best values compared to other qualities of irrigation water.

The treatment of Kinetin with $40 \mathrm{mg} . \mathrm{L}^{-1}$ record the upper values without significant difference from $20 \mathrm{mg} . \mathrm{L}^{-1}$, while the lower values were at control treatment.

the interaction between water quality, kinetin treatment record the significant difference between the values, the treatment which irrigated with $1.2 \mathrm{dS} . \mathrm{m}^{-1}$ and treated with $40 \mathrm{mg} . \mathrm{L}^{-1}$ and $20 \mathrm{mg} . \mathrm{L}^{-1}$ record highest values table (6).

Table 6. Effect of water quality, kinetin treatment on leaves contents of P\%

\begin{tabular}{|c|c|c|c|c|}
\hline \multirow{2}{*}{$\begin{array}{l}\text { Water } \\
\text { quality }\end{array}$} & \multicolumn{3}{|c|}{ Kinetin mg. $\mathrm{L}^{-1}$} & \multirow{2}{*}{$\begin{array}{c}\text { Effect of } \\
\text { Water quality }\end{array}$} \\
\hline & 0 & 20 & 40 & \\
\hline $1.2 \mathrm{dS} . \mathrm{m}^{-1}$ & 1.587 & 2.487 & 2.643 & 2.239 \\
\hline $5 \mathrm{dS} \cdot \mathrm{m}^{-1}$ & 1.023 & 1.337 & 1.420 & 1.260 \\
\hline \multirow[t]{3}{*}{$10 \mathrm{dS} \cdot \mathrm{m}^{-1}$} & 0.553 & 0.763 & 0.863 & 0.727 \\
\hline & \multicolumn{3}{|c|}{ L.S.D0.05 } & L.S.D 0.05 \\
\hline & \multicolumn{3}{|c|}{0.4566} & 0.4501 \\
\hline $\begin{array}{c}\text { Effect of } \\
\text { Kinetin }\end{array}$ & 1.054 & 1.529 & 1.642 & \\
\hline L.S.D 0.05 & & 0.180 & & \\
\hline
\end{tabular}


Current Trends in Natural Sciences

Vol. 10, Issue 19, pp. 457-465, 2021

https://doi.org/10.47068/ctns.2021.v10i19.061

Current Trends in Natural Sciences (on-line)

Leaves contents of $\mathbf{K} \%$ : Table (7) showed that saline water reduced the leave contents of $\mathrm{K}$ significantly, the lower values were the treatments that irrigated with $10 \mathrm{dS} . \mathrm{m}^{-1}$, while the treatments which irrigated with $1.2 \mathrm{dS} . \mathrm{m}^{-1}$ record the best values.

Kinetin improved the $\mathrm{K}$ ratio in leaves, the treatments of $40 \mathrm{mg} \cdot \mathrm{L}^{-1}$ record the highest values without significant difference from $20 \mathrm{mg} \cdot \mathrm{L}^{-1}$.

Table 7. Effect of water quality, kinetin treatment on leaves contents of K\%

\begin{tabular}{|c|c|c|c|c|}
\hline \multirow{2}{*}{$\begin{array}{l}\text { Water } \\
\text { quality }\end{array}$} & \multicolumn{3}{|c|}{ Kinetin $\mathrm{mg} \cdot \mathrm{L}^{-1}$} & \multirow{2}{*}{$\begin{array}{c}\text { Effect of } \\
\text { Water quality }\end{array}$} \\
\hline & 0 & 20 & 40 & \\
\hline $1.2 \mathrm{dS} \cdot \mathrm{m}^{-1}$ & 2.517 & 2.833 & 2.857 & 2.736 \\
\hline $5 \mathrm{dS} \cdot \mathrm{m}^{-1}$ & 1.987 & 2.133 & 2.240 & 2.120 \\
\hline \multirow[t]{2}{*}{$10 \mathrm{dS} \cdot \mathrm{m}^{-1}$} & 1.520 & 1.713 & 1.880 & 1.704 \\
\hline & \multicolumn{3}{|c|}{ L.S.D 0.05} & $\begin{array}{c}\text { L.S.D } 0.05 \\
0.1792\end{array}$ \\
\hline $\begin{array}{c}\text { Effect of } \\
\text { Kinetin }\end{array}$ & 2.517 & 2.833 & 2.857 & \\
\hline L.S.D 0.05 & & 0.115 & & \\
\hline
\end{tabular}

\section{Leaves content of $\mathrm{Na} \& \mathrm{Cl}$ :}

The contents of $\mathrm{Na} \& \mathrm{Cl}$ in leaves of Spinach plants (Table $8 \&$ 9) increased with increasing salinity. Ion accumulation was much greater at the treatment, which irrigated with $10 \mathrm{dS} . \mathrm{m}^{-1}$, while the lower contents of $\mathrm{NaCl}$ were the treatment, which was irrigated with $1.2 \mathrm{dS} . \mathrm{m}^{-1}$.

The Kinetin treatment due to reducing the values of $\mathrm{Na} \& \mathrm{Cl}$ contents in leaves, the ions accumulation was much lower at the $40 \mathrm{mg} . \mathrm{L}^{-1}$ concentration, the highest values were at the control treatment. the data in tables $(8 \& 9)$ showed significant differences between treatments, the lower contents of $\mathrm{Na} \& \mathrm{Cl}$ in leaves at the treatments which irrigated with $1.2 \mathrm{dS} . \mathrm{m}^{-1}$ and treated or untreated with Kinetin, while the highest values at the treatments which irrigated with 10 dS.m ${ }^{-1}$ that which untreated with Kinetin but the results at a tables $(8,9)$.

Table 8. Effect of water quality, kinetin treatment on leaves contents of $\mathrm{Na} \%$

\begin{tabular}{cccr} 
Water quality & \multicolumn{3}{c}{ Kinetin mg.L $\mathrm{L}^{-1}$} \\
& 0 & 20 & 40 \\
$1.2 \mathrm{dS} . \mathrm{m}^{-1}$ & 1.010 & 0.960 & 0.993 \\
$5 \mathrm{dS} . \mathrm{m}^{-1}$ & 4.213 & 4.037 & 4.093 \\
$10 \mathrm{dS} . \mathrm{m}^{-1}$ & 8.223 & 7.103 & 6.76 \\
& & L.S.D 0.05 & \\
& & N.S & \\
Effect of & 4.482 & 4.033 & 3.949 \\
Kinetin & & & \\
L.S.D 0.05 & & 0.446 &
\end{tabular}

Table 9. Effect of water quality, kinetin treatment on leaves contents of $\mathrm{Cl} \%$

\begin{tabular}{|c|c|c|c|c|}
\hline \multirow{2}{*}{$\begin{array}{c}\text { Effect of } \\
\text { Water quality }\end{array}$} & \multirow{2}{*}{ Water quality } & \multicolumn{3}{|c|}{ Kinetin mg.. $\mathrm{L}^{-1}$} \\
\hline & & 0 & 20 & 40 \\
\hline & $1.2 \mathrm{dS} . \mathrm{m}^{-1}$ & 2.143 & 2.293 & 2.110 \\
\hline 4.114 & $5 \mathrm{dS} \cdot \mathrm{m}^{-1}$ & 5.430 & 4.310 & 4.467 \\
\hline 7.362 & 10 dS.m $\mathrm{m}^{-1}$ & 7.283 & 6.450 & 6.507 \\
\hline L.S.D 0.05 & & & L.S.D 0 & \\
\hline \multirow[t]{3}{*}{0.5657} & & & 0.307 & \\
\hline & $\begin{array}{c}\text { Effect of } \\
\text { Kinetin }\end{array}$ & 4.952 & 4.351 & 4.361 \\
\hline & L.S.D 0.05 & & 0.168 & \\
\hline
\end{tabular}

Effect of Water quality 2.182

4.736

6.747

L.S.D 0.05 0.2582

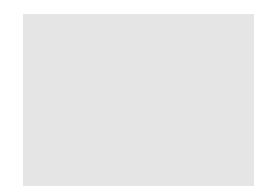




\section{The activity of Peroxidase in leaves:}

Table (10) indicated that increased in the activity of Peroxidase under salt stress, the high values were at the treatment which irrigated with $5 \mathrm{dS} . \mathrm{m}^{-1}$ without significant difference from $10 \mathrm{dS} . \mathrm{m}^{-1}$ the lower values were at the treatment that which irrigated with $1.2 \mathrm{dS} . \mathrm{m}^{-1}$ water, Kinetin treatment record a significant differences on the activity of Peroxidase in leaves; the best concentration was $40 \mathrm{mg} \cdot \mathrm{L}^{-1}$.

The interaction recorded a significant difference between treatments, the high values at the treatment which irrigated with $5 \& 10 \mathrm{dS} . \mathrm{m}^{-1}$ that treated with $40 \mathrm{mg} . \mathrm{L}^{-1}$ of Kinetin. The interaction recoreded a significant differences between treatments, the high values at treatment which irrigated with $5 \& 10 \mathrm{dS} . \mathrm{m}^{-1}$ that treated with $40 \mathrm{mg} . \mathrm{L}^{-1}$ of Kinetin.

Table 10. Effect of water quality, kinetin treatment activity of Peroxidase in leaves

\begin{tabular}{|c|c|c|c|c|}
\hline \multirow{2}{*}{$\begin{array}{l}\text { Water } \\
\text { quality }\end{array}$} & \multicolumn{3}{|c|}{ Kinetin mg. $\mathrm{L}^{-1}$} & \multirow{2}{*}{$\begin{array}{c}\text { Effect of } \\
\text { Water quality }\end{array}$} \\
\hline & 0 & 20 & 40 & \\
\hline $1.2 \mathrm{dS} . \mathrm{m}^{-1}$ & 0.0985 & 0.1184 & 0.1318 & 0.1162 \\
\hline $5 \mathrm{dS} . \mathrm{m}^{-1}$ & 0.1255 & 0.1343 & 0.1383 & 0.1327 \\
\hline \multirow[t]{3}{*}{$10 \mathrm{dS} \cdot \mathrm{m}^{-1}$} & 0.1258 & 0.1339 & 0.1360 & 0.1319 \\
\hline & \multicolumn{3}{|c|}{ L.S.D 0.05} & L.S.D0.05 \\
\hline & \multicolumn{3}{|c|}{0.0110} & 0.0106 \\
\hline $\begin{array}{c}\text { Effect of } \\
\text { Kinetin }\end{array}$ & 0.1166 & 0.1288 & 0.1353 & \\
\hline L.S.D 0.05 & & 0.0047 & & \\
\hline
\end{tabular}

The activity of Catalase in leaves:

The results in table (11) indicated significant differences between the salinity levels of irrigation water on Catalase activity in leaves, the highest value at the treatment which irrigated with $5 \mathrm{dS}^{-1} \mathrm{~m}^{-1}$. The Kinetin treatment achieved a positive effect to increase the activity of catalase in both of Kinetin concentrations, while the lower average was at control treatments, the interaction record significant difference between treatments, the best value at treatments which irrigated with $5 \mathrm{dS} . \mathrm{m}^{-1}$ and treated with both of Kinetin concentrations.

Table 11. Effect of water quality, kinetin treatment activity of Catalase in leaves

\begin{tabular}{ccccc} 
Water & \multicolumn{3}{c}{ Kinetin mg.L-1 } & $\begin{array}{c}\text { Effect of } \\
\text { quality }\end{array}$ \\
Water quality
\end{tabular}


Results above indicated that salt stress causes a reduction in growth, development, and inhibited the photosynthesis, respiration, and protein synthesis, and disturbs nucleic acid metabolism, that salinity suppressed both cell diffusion and cell enlargement (Saker \& El-Metwally, 2009; Al-Taey and Saadoon, 2014; AL-Taey et al.,2019), or maybe revert to Turgor pressure reductions in expanding tissues, reductions in the photosystem activity, and direct effects of accumulated salt on critical metabolic steps in dividing and expanding cells (Al-Taey et al.,2017), Ersalan (2008 ) indicated that significant reduction in dry weight of root in spinach plant under salt stress.

The diminution of nutrient ions in leaves that revert to high $\mathrm{Na}$ and $\mathrm{Cl}$ concentration disturbance in the accumulation of nutrients, Salinity affects nutrients uptake at two levels: by direct competition of Sodium \& chloride or by affecting cell membranes permeability through membrane proteins by changing plasma lemma integrity (Meloni et al., 2004), Khan (2010) reported that salt stress causes reduced of NPK contents and increasing $\mathrm{Na}, \mathrm{Cl}$ in bean plants.

Plants under stress conditions tend to increase the Peroxidase activity and it is sometimes the first enzyme with an alteration in activity, independently of the substratum or the applied stress. Peroxidase can be considered a biochemical marker of biotic as well as abiotic stress situation; moreover, it seems to be a key molecule of plant adaptation, or of some plant organs separately, to environmental changes (Eraslan et al., 2008; Al-Azawi, 2015; Al-Taey, and Majid,2018) reported that activity of Catalase and Peroxidase increased under salt stress, while Farouk (2011) mention to that Catalase and Peroxidase, were characterized by a gradual reduction with increasing sodium chloride salinity levels up to11.5 dS.m ${ }^{-1}$.

Seed enhancement (seed priming) with Cytokinines is reported to increase plant salt tolerance (Iqbal et al., 2006; Al-Taey,2017), the Kinetin treatment deleterious effects of salt stress on many plants that may be returned to acts as a direct free radical scavenger or it may involve in ant oxidative mechanism related to the protection of purine breakdown (Javid et al., 2011), A possible involvement of genes in stress responses is often inferred from changes in the transcript abundance in response to a given stress trigger. An overview of the many changes in the transcript abundance of Cytokinines genes in Arabidopsis in response to environmental factors was given elsewhere (Argueso et al., 2009).

\section{CONCLUSIONS}

Saline water of $10 \mathrm{dS} . \mathrm{m}^{-1}$ led to reducing the growth parameters, yield in Spinach while the $\mathrm{NaCl}$ contents and activity of CAT and POX increased with raised of saline water until $10 \mathrm{dS} . \mathrm{m}-1$, while the Kinetin treatment led to improve the growth and yield especially under salt stress in both of kinetin levels 20 and $40 \mathrm{mg} . \mathrm{L}^{-1}$.

\section{REFERENCES}

Abass, D.K., al-Janabi, A.H., Rachid, M.A. (2015). Effect of irrigation water quality and organic and mineral fertilization on the availability of some nutrient elements and cabbage yield (Brassica oleraceae var. capitata L.). Euphrates Journal of Agriculture Science, 7(4), 235-247.

Abbassi, K., Mergaoui, L., Atay-Kadiri, Zn., Stambouli, A., Ghaout, S. (2003). Effets des extraits de Peganum harmala (Zygophyllaceae) sur le criquet pèlerin (Schistocerca gregaria, Forskål, 1775) [Effects of Peganum harmala (Zygophyllaceae) extracts on desert locust (Schistocerca gregaria, Forskål, 1775)]. Zoologica baetica, 14, 203217.

Adam, A.L., Bestwick, C.S., Barna, B., Mansfield, J.W. (1995). Enzymes regulating the accumulation of active oxygen species during the hypersensitive reaction of bean to Pseudomonas syringae pv. Phaseolicola. Planta 197, 204249.

Aebi, H.E. (1983). Catalase. In: Bergmeyer HV (Eds) Methods of Enzymatic Analysis, Velar Weinheim, $273-286$. 


\section{Current Trends in Natural Sciences}

Vol. 10, Issue 19, pp. 457-465, 2021

https://doi.org/10.47068/ctns.2021.v10i19.061

Current Trends in Natural Sciences (on-line)

ISSN: 2284-953X

Current Trends in Natural Sciences (CD-Rom)

ISSN: 2284-9521

ISSN-L: 2284-9521

ISSN-L: 2284-9521

Al-Azawi, S.S.M.(2015). Effect of Water Quality and Kinetin Treatment on Growth and Catalase Activity of Maize Seedlings (Zea mays L.) Journal of Babylon University/Pure and Applied Science, 4 (23), 1667-1685.

Al-Khafajy, R.A., AL-Taey, D. K.A., AL-Mohammed, M.H.S.(2020). The impact of Water Quality, Bio fertilizers and Selenium Spraying on some Vegetative and Flowering Growth Parameters of Calendula Officinalis L. under Salinity Stress. Int. J. Agricult. Stat. Sci., 16 Supp 1, 1175-1180.

Al-Taey, D.K.A., Majid, Z. Z. (2018). Study Effect of Kinetin, Bio-fertilizers and Organic Matter Application in Lettuce under Salt Stress. Journal of Global Pharma Technology, 10(1), 148-164.

AL-Taey, D.K.A., Al-Janabi, A.S.H., Rachid, A.M. (2017). Effect of water salinity, Organic and minerals fertilization on growth and some nutrients elements in cabbage Brassica oleracea var apitate. Babylon journal of Pure and Applied science, 25(6), 232- 248.

AlTaey, D.K.A. (2017). Alleviation of Salinity Effects by Poultry Manure and Gibberellin Application on growth and Peroxidase activity in pepper. International Journal of Environment, Agriculture and Biotechnology,2(4), 18511862.

Al-Taey, D.K.A. Saadoon, A.H. (2012). Effect of treatment of kinetin to reduce the salinity damage by drainage water irrigation on the growth and nitrate accumulation in the leaves of spinach, Spenacia oleracea L. Euphrates Journal of Agriculture Science. 4 (4), 11-24.

Al-Taey, D.K.A. (2009). Effect of spraying acetyl salicylic acid to reduce the damaging effects of salt-water stress on orange plants (Citrus sinensis L.). Journal of Kerbala University, 7 (2), 192-202.

Al-Taey, D.K.A., AL-Naely, I J.C., Kshash B.H. (2019). A study on effects of water quality, cultivars, organic and chemical fertilizers on potato (Solanum tuberosum L.) growth and yield to calculate the economic feasibility. Bulgarian Journal of Agricultural Science, 25 (6), 1239 -1245.

Al-Taey, D.K.A., AlAzawi, S.S.M., Husien, M.H. (2009). Effect of Spraying Acetyl Salicylic Acid on the Plant Tolerance for Salt Stress \& Survival Percentage after Transplanting of Orange (Citrus sinensis). Babylon journal university -Pure and Applied science, 18 (4), 1513-1520.

Argueso, C.T., Ferreira, F.J., Kieber, J.J. (2009) Environmental perception avenues: the interaction of cytokinin and environmental response pathways. Plant Cell Environ 32, 1147-1160.

Eraslan, F., Inal, A., Pilbeam, D. J, Gunes, A. (2008) Interactive effects of salicylic acid and silicon on oxidative damage and antioxidant activity in spinach (Spinacia oleracea L. cv. Matador) grown under boron toxicity and salinity. Plant Growth Regul, 55, 207-219.

Hamza, O.M., AL-Taey, D. K. A. (2020). A study on the effect of glutamic acid and benzyl adenine application up on growth and yield parameters and active components of two Broccoli hybrids. Int. J. Agricult. Stat. Sci., 16 Supp1, 1163-1167.

Iqbal, M., Ashraf, M., Jamil A. (2006). Seed enhancement with cytokinins: changes in growth and grain yield in salt stressed wheat plants. Plant Growth Regul, 50, 29-39

Javid, M.J., Sorooshzadeh, A., Moradi, F., Sanavy, S.A.M., Allahdadi I. (2011). The role of Phytohormones in alleviating salt stress in crop plants. Australian Journal of Crop Science. 5(6), 726-734.

Kaya, C., Higgs, D., Kirnak, H. (2001). The effects of high salinity ( $\mathrm{NaCl}$ ) and supplementary phosphorus and pottacium on physiology and nutration development of Spinach. Bulg. J. Plant Physiol., 27(3-4),47-59.

Khan, A., Syeed, S., Masood, A., Nasar, R., Iqpal N.(2010). Application of salicylic acid increases contents of nutrients and antioxidative metabolism in mung bean and alleviates adverse effects of salinity stress. International Journal of Plant Biology 2010, 1:e1.

Meloni, D.A., Gulotta, M.R., Martinez, C.A., Oliva, M.A. (2004). The Effects of Salt Stress on Growth, Nitrate Reduction and Proline and Glycinebetaine Accumulation in Prosopis alba. Braz. J. Plant Physiol. 16(1),39-46.

Page, A. L., Miller, R. H., Keeney D. R. (1982). Methoed of soil and analysis Part 2, $2^{\text {nd }}$ ed, Agron. 9. Publisher, Madison, Wisconsin, USA.

Richards, L.A. (1954). Diagnosis and improvement of saline and alkaline soils. USDA Agric. Handbook, Vol. 66, U.S. Department of Agriculture.

Saker, M.T., El-Metwaly, M.A. (2009). Alleviation of harmful effect of soil salt stress on growth, yield \& endogenous antioxidant contents of wheat by application antioxidants. Pakistan Journal of Biological Science, 12(8), 624630.

Shabir, H. W., Kumarb, V., Shriramc, S., Sah, K. (2016). Phytohormones and their metabolic engineering for abiotic stress tolerance in crop plants. The crop journal, 162-176.

Shannon, M.C., Grieve, C.M. (1999). Tolerance of Vegetable Crops to Salinity. Scientia Horticulturae, 78, 5-38. http://dx.doi.org/10.1016/S0304-4238(98)00189-7 